\title{
DEMOKRASI POST-PENYIARAN DALAM MUNCULNYA FANS POLITIK DI INDONESIA
}

\author{
Vannyora Okditazeini
}

IAIN Batusangkar, Batusangkar, Indonesia

vannyora@iainbattusangkar.ac.id

\begin{abstract}
This study aims to elaborate on how the pattern of democracy shifts along with the development of technology and communication. This shift can be seen from the use of broadcast media as a channel of aspirations to the use of new media known as post-broadcasting democracy. This post-broadcasting democratic pattern will be seen on the \#2019gantippresi fanpage community and will analyze the activities carried out by members in the group. This paper is a netnographic study by integrating the concepts of mediated politics, post-broadcasting democracy, and political fans. The results of the study show that this shift in the pattern of democracy creates a new phenomenon, namely political fans. This can be seen in: first, the activities carried out by political fans on social media foster a political constellation with high mobility. Second, post-broadcasting democratic publics become interactive publics. Third, political fans produce texts which in turn become cultural productions in mediated politics. Fourth, the activities of these political fans indirectly influence public opinion regarding the political actors they admire. The author observes that the phenomenon of political fans as seen on the \#2019gantippresi fanspage can be a new strategy for political actors in growing fanatical sympathizers by utilizing technological and communication developments.
\end{abstract}

Keywords: Facebook Fanspage; Post-Broadcast Democracy; Political Fans; Social Media; \#2019gantipresiden

\begin{abstract}
Abstrak
Penelitian ini bertujuan untuk mengelaborasi bagaimana pola demokrasi bergeser seiring dengan perkembangan teknologi dan komunikasi. Pergeseran ini terlihat dari yang tadinya menggunakan media penyiaran sebagai penyalur aspirasi kepada penggunaan media baru yang dikenal dengan demokrasi post-penyiaran. Pola demokrasi post-penyiaran ini akan dilihat pada komunitas fanspage \#2019gantipresiden dan akan menganalisis aktivitas yang dilakukan anggota dalam grup tersebut. Tulisan ini merupakan studi netnografi dengan mengintegrasikan konsep tentang politik yang dimediasi, demokrasi post-penyiaran, dan fans politik. Hasil penelitian menunjukkan bahwa pergeseran pola demokrasi ini menumbuhkan fenomena baru, yaitu fans politik. Hal ini terlihat pada: pertama, aktivitas yang dilakukan fans politik di media sosial menumbuhkan konstelasi politik dengan mobilitas yang tinggi. Kedua, publik demokrasi post-penyiaran menjadi publik yang interaktif. Ketiga, fans politik memproduksi teks yang pada akhirnya menjadi produksi budaya dalam politik yang dimediasi. Keempat, aktivitas fans politik ini secara tidak langsung mempengaruhi opini publik terkait aktor politik yang mereka kagumi. Penulis mengamati, fenomena fans politik seperti yang terlihat pada fanspage \#2019gantipresiden dapat menjadi strategi baru bagi para aktor politik dalam menumbuhkan simpatisan yang fanatik dengan memanfaatkan perkembangan teknologi dan komunikasi.
\end{abstract}

Kata Kunci: Demokrasi Post-Penyiaran; Fans Politik; Fanspage Facebook; Media Sosial; \#2019gantipresiden. 


\section{PENDAHULUAN}

Artikel ini mengelaborasi bagaimana penggunaan media sosial dalam kaitannya dengan perkembangan teknologi membuat pola demokrasi menjadi bergeser dan memunculkan fanboy/fangirl dalam kancah politik. Hal ini terlihat dari berbagai interaksi yang terjadi di antara pengguna media sosial tersebut dalam memproduksi teks yang bermuatan politis dan sebagai penanda hal baru dalam demokrasi. Hal ini diistilahkan Mazzoleni dan Schultz (1999) dengan 'politik yang dimediasi'. Politik yang dimediasi dalah istilah yang merujuk pada kegiatan yang bermuatan konten politik pada suatu subjek via media massa dengan segala aturan, tujuan, logika produksi, dan hambatannya (Wilson, 2011, p. 445).

Media adalah salah satu pembentuk makna yang signifikan dalam komunikasi politik (Afriadi, Prisanto, Ernungtyas, Irwansyah, \& Afriani, 2019, p. 150). Dalam politik ( $\mathrm{k}$ yang dimediasi, media sosial sebagai wadah untuk mewujudkan partisipasi politik dipandang penting untuk aktor politik, partai politik, jurnalis, dan bahkan partisan politik. Bentuk partisipasi di media sosial ini bisa dengan berbagai tujuan; meningkatkan kesadaran akan situasi politik, strategi untuk mempererat ikatan dengan publik online, ataupun untuk komunikasi politik secara langsung dalam kapasitas profesional (Burgess \& Bruns, 2012, p. 384).

Jika dahulu wadah untuk menyalurkan kebebasan ini dilakukan dengan media yang membutuhkan penyiaran seperti televisi atau radio, di era digital sekarang hal tersebut telah berubah. Perkembangan media komunikasi terlebih dalam berinteraksi dengan orang lain, membuat media sosial menjadi populer dan secara inheren menciptakan ruang demokrasi baru bagi masyarakat. Terlebih sifat media sosial dengan tingkat mobilitas yang tinggi memungkinkan setiap orang dapat berinteraksi dimana saja dan kapan saja.
Didalam media sosial individu maupun kelompok saling berinteraksi secara online melalui jejaring internet dan semenjak kemunculannya media sosial tidak hanya dipergunakan oleh individu saja melainkan juga oleh kelompok atau golongan sebagai alat komunikasi yang dianggap cukup membantu bahkan juga dipergunakan sebagai alat komunikasi yang efektif untuk tegur sapa kepada publik (Haqqi, 2020, p. 181).

Platform baru dalam menyuarakan demokrasi di media sosial menjadi hal yang menarik dalam perubahan komunikasi politik didunia. Sosial media seperti Twitter, Facebook, YouTube, Wikies, Blogsphere, dan lain-lain, menjadikan demokrasi post-penyiaran sebagai alternatif baru dalam strategi komunikasi politik para aktor politik dan partai politik tertentu, terlebih dalam meningkatkan ikatan antar sesama publik (Loader \& Mercea, 2011, p. 758).

J. E Cohen (2009) dalam bukunya Going Local: Presidential Leadership in the Post-Broadcast Age menggarisbawahi bahwa kegiatan politik di era 1990an dan 2000an dimana internet menjadi sangat berkembang merupakan transisi dari "going national" (tersebar luas)—perhatiannya fokus pada bagaimana informasi politis bisa tersebar secara nasional-kepada "going narrow" (terpusat) — fokus pada penyebaran informasi politis ke media lokal dan kelompok-kelompok tertentu (Hoffman, 2011, p. 611).

Demokrasi terwujud tidak hanya melalui media penyiaran namun juga melalui media non-penyiaran seperti media sosial yang belakangan ini disinyalir dapat mempengaruhi proses pemilihan dalam politik. Pilihan seseorang untuk mengkonsumsi konten politik dan menyalurkannya melalui media sosial miliknya adalah bentuk demokrasi yang tidak lagi harus bergantung pada televisi atau radio untuk menyalurkan aspirasinya. 
Namun beralih kepada demokrasi postpenyiaran.

Penelitian yang dilakukan oleh HsinChen Lin dari University of New Brunswick, Canada pada tahun 2017 tentang How Political Cadidates' Use of Facebook Relates to the Election Outcomes menunjukkan bahwa dengan adanya Facebook dan media sosial lainnya sebagai perpanjangan tangan kandidat politik atau aktor politik, membuat mereka semakin mempunyai peluang besar dalam memenangkan pemilu. Penelitian yang dilakukan terhadap 84 kandidat yang mengajukan diri pada pemilihan walikota di Taiwan ini juga memperlihatkan bahwa kehadiran media sosial dari kandidat politik, mulai dari banyaknya akun yang mereka gunakan, otentikasi akun (centang biru pada akun), dan jumlah pengikut (followers), memiliki kaitan yang erat dengan hasil pemilu mereka (Lin, 2017, p. 77).

Penelitian lain yang dilakukan oleh Budzinki et al (2020) terhadap 3000 orang warga Jerman antara tahun November 2018 sampai dengan Februari 2019 menunjukkan bahwa generasi muda lebih memilih untuk menonton suatu konten melalui Youtube atau Netflix dibandingkan harus menyalakan televisi mereka (Thurman, 2020, p. 5). Ini memperlihatkan bahwa media sosial seperti Youtube sekarang menjadi pilihan bagi masyarakat untuk mengkonsumsi suatu konten, baik iu konten politik sekalipun, dan tidak bergantung pada media penyiaran lagi.

Simpatisan fanatik dari tokoh-tokoh ini kemudian memunculkan apa yang disebut dengan fans politik. Seperti yang pernah disebutkan oleh Ketua Umum PP Muhammadiyah, Dahnil Anzar Simanjutak bahwa publik Indonesia sekarang berubah menjadi fanboy/fangirl dan akan matimatian membela sosok yang mereka kagumi (Fadhil, 2018). Apalagi di tahun 2019, Indonesia menghadapi pemilihan umum presiden, sehingga bisa dipastikan polarisasi politik akan sangat banyak terjadi di tahun politik tersebut. Tidak ada bedanya dengan fans-fans yang lain, fans politik justru juga memuja dan mengelu-elukan sosok politisi tertentu dan cenderung akan membela habis-habisan sosok tersebut. Pun mereka mempunyai halaman fans sendiri dalam media sosial sebagai tempat bagi mereka untuk berbagi informasi terbaru, update kegiatan terbaru, memes yang memojokkan oposisi, hingga fanwar dengan fans dari politisi oposisi.

Kajian tentang fans merupakan studi yang sudah lama dan banyak menarik perhatian para akademisi. Kebanyakan kajian fans ini terlihat dalam dunia hiburan. Belum banyak yang meneliti tentang fans politik terutama yang berkaitan dengan era digital. Namun begitu, konsep fans politik sangat menarik untuk diangkat, terlebih karena pada dasarnya fans politik tidak jauh berbeda dengan fans-fans yang lainnya. Simpatisan partai politik ini sejalan dengan apa yang diistilahkan Maizhevich (2018) dengan digital participatory online atau partisipan digital. Menurutnya, pergeseran pilihan penonton pada media postpenyiaran mengakomodasi fleksibilitas pada penonton (dapat ditonton berulang kali), merubah 'selera' penonton, dan menumbuhkan personalisasi (Miazhevich, 2018, p. 16).

Penulis mengamati bahwa polarisasi fans politik di Indonesia terhadap pemilihan umum presiden tahun 2019 menimbulkan sebuah gerakan baru yang sangat viral di media sosial yaitu gerakan \#2019gantipresiden. Gerakan ini adalah sebuah tagar yang digunakan di Twitter untuk menyatakan ketidakberpihakan kepada presiden Indonesia saat itu yaitu Joko Widodo. Gerakan ini viral ketika pertama kali digunakan oleh Mardani Ali Sera dari partai oposisi PKS pada bulan April 2018. Begitu viralnya hingga berbagai macam produk dihasilkan dengan menggunakan tagar ini. Mulai dari kaos, pin, desain topi, dan lain-lain. Tagar ini 
kemudian diadopsi di Facebook dan memobilisasi publik untuk secara luas menyebarkan gerakan ini.

Gerakan \#2019GantiPresiden ini diadopsi dan kemudian menjadi salah satu ikon pada banyak komunitas atau kelompok di dunia maya. Tak terkecuali fanspage \#2019GantiPresiden. Penelitian tentang komunitas dalam ruang maya sudah banyak dilakukan dan selalu menarik dengan wacana politik tertentu. Seperti penelitian yang dilakukan oleh Astuti \& Toni pada tahun 2020 tentang media sosial sebagai sarana bagi komunitas untuk meningkatkan eksistensi dalam wacana politik pemilu tahun 2019. Penelitian dilakukan terhadap komunitas Net.Good People dan hasil penelitian memperlihatkan bahwa komunitas memegang peranan yang penting dalam menjaga eksistensi wacana politik dalam masyarakat (Astuti \& Toni, 2020. , p. 11). Ini menunjukkan bahwa komunitas fanspage \#2019GantiPresiden juga bisa menjafi peranan yang penting dalam melancarkan wacana atau isu-isu politik tertentu.

Berdasarkan dataWeAreSocial.net dan Hootsuite 2017, perkembangan penggunaan internet di Indonesia sangat pesat, yakni tumbuh $51 \%$ dalam kurun waktu satu tahun. Dengan angka pertumbuhan yang jauh melampaui angka pertumbuhan penggunaan internet di dunia, yaitu $10 \%$, Indonesia menempati urutan ke dua pengguna internet terbesar sejagat (katadata, 2018). Lebih dari $69 \%$ masyarakat Indonesia mengakses internet dengan menggunakan perangkat mobile mereka. Angka tersebut juga melampaui penggunaan internet via mobile secara global, yakni 50\%. Angka tersebut tertinggi ke empat di duni. Hasil survey globalwebindex pada pengguna internet di Indonesia dalam rentang usia 16-64 tahun, menunjukkan bahwa ada beberapa platform media sosial yang aktif digunakan oleh masyarakat Indonesia. Platform tersebut terbagi dalam dua kategori media sosial, yaitu media jejaring sosial dan messenger.
Youtube menempati peringkat pertama dengan persentase penggunaan sebesar $43 \%$, di peringkat ke dua Facebook dengan persentase penggunaan sebesar $41 \%$, kemudian Whatsapp dengan persentase penggunaan sebesar 40\% (katadata, 2018).

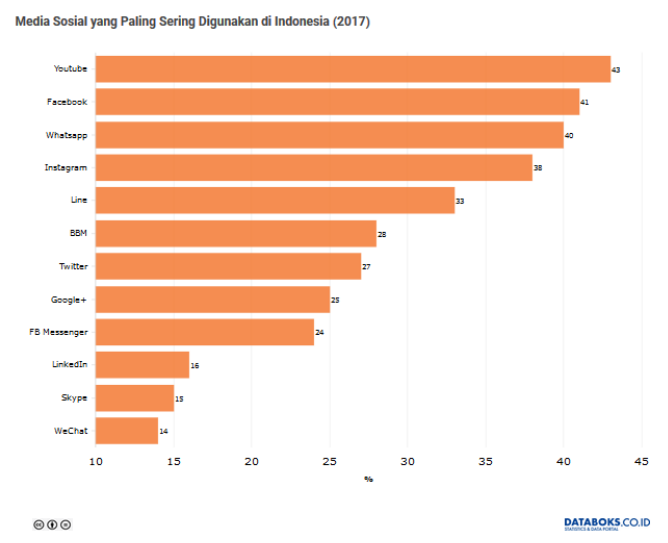

Gambar 1. Media Sosial yang Paling Sering Digunakan di Indonesia (2017) Sumber: (katadata, 2018).

Berdasarkan gambar 1, Facebook merupakan alternatif bagi masyarakat Indonesia untuk berinteraksi secara virtual dengan orang lain. Maka gerakan \#2019gantipresiden disinyalir sangat efektif untuk bisa tersebar luas secara viral di dunia maya melalui media sosial Facebook. Penulis mengamati bahwa fanspage \#2019gantipresiden merupakan fanspage yang paling banyak disukai di Facebook dengan jumlah like sebanyak 362.000 . Fanspage ini merupakan fanspage politis yang paling banyak disukai. Oleh karena itulah penulis tertarik untuk melihat bagaimana aktivitas fans di fanspage ini. Untuk memahami hal ini, penulis akan mensintesakan pemikirannya bagaimana kelompok-kelompok tertentu yang dalam hal ini adalah simpatisan tokoh tersebut membuat konstelasi dari mobilitas, publik yang interaktif, dan teks yang diproduksi sebagai produksi budaya dalam politik yang dimediasi, serta pengaruh aktivitas fans tersebut pada opini publik. 
Dengan dasar tersebut, maka penulis akan menawarkan analisis bagaimana pergeseran demokrasi khususnya di media sosial dalam menumbuhkan fans politik di Indonesia. Oleh karena itu, peneliti membatasi tujuan penelitian pada pertanyaan bagaimana bentuk demokrasi post-penyiaran yang terlihat dari aktivitas fans pada fanspage \#2019gantipresiden?

\section{METODOLOGI}

Penelitian ini menggunakan paradigma konstruktivis atau paradigma interpretif. Dengan begitu, peneliti berupaya melihat bagaimana aktivitas fans politik dalam ruang obrolan fanspage \#2019gantipreseiden dalam hubungannya dengan demokrasi post-penyiaran. Strategi penelitian yang digunakan dalam penelitian ini adalah metode Netnografi. Netnografi mengadaptasi prosedur umum dari etnografi dalam hal observasi partisipan atau observasi terlibat ke kontingensi unik interaksi sosial yang dimediasi oleh komputer (Kozinets, 2010, p. 58). Etnografi adalah rancangan penelitian yang berasal dari antropologi dan sosiologi yang di dalamnya peneliti menyelidiki pola perilaku, bahasa, dan tindakan dari suatu kelompok kebudayaan di lingkungan yang alamiah dalam periode waktu yang cukup lama (Creswell, 2014, p. 19). Di masa kini, banyak orang menggunakan internet sebagai media untuk berkomunikasi dengan orang lain dan menggunakannya dalam pembentukan komunitas. Etnografi online mengacu pada sejumlah metode penelitian online yang beradaptasi dengan studi komunitas dan budaya, yang diciptakan melalui interaksi sosial yang dimediasi oleh komputer (Kozinets, 2010, p. 40). Etnografi online ini adalah apa yang juga dinamakan oleh Kozinets sebagai Netnografi. Karena yang menjadi subyek penelitian ini adalah warganet di fanspage \#2019gantipresiden, dimana peneliti disini juga berada dalam posisi sebagai bagian dari komunitas \#2019gantipresiden itu sendiri, dan peneliti ingin melihat aktivitas yang dilakukan fans politik dalam fanspage tersebut, maka strategi netnografi menurut peneliti tepat digunakan dalam penelitian ini.

Pada penelitian dengan menggunakan metode netnografi, penelitian dilakukan dengan melakukan pengamatan yang didasarkan pada kerja lapangan online, dimana ia menggunakan komunikasi yang dimediasi komputer sebagai sumber data untuk sampai pada pemahaman etnografi dan representasi fenomena budaya atau komunal (Kozinets, 2010, p. 60). Dalam banyak kasus, netnografi menggunakan informasi yang tersedia untuk publik di forum online (Kozinets, 2010, p. 56). Forum online dalam penelitian ini adalah fanspage \#2019gantipresiden. Fanspage ini merupakan fanspage dari Facebook yang menjadi wadah interaksi para warganet dengan berbagai macam topik pembahasan mengenai \#2019gantipresiden.

Subyek penelitian dalam penelitian ini adalah warganet dalam ruang obrolan fanspage \#2019gantipresiden. Sedangkan metode pengumpulan data dalam penelitian ini adalah observasi atau pengamatan. Observasi kualitatif adalah ketika peneliti langsung turun ke lapangan untuk mengamati perilaku dan aktivitas individuindividu di lokasi penelitian, dan dalam pengamatan ini, peneliti merekam atau mencatat dengan cara terstruktur maupun semistruktur aktivitas-aktivitas di lokasi penelitian (Creswell, 2014, p. 254). Dalam penelitian ini, peneliti akan menjelaskan secara deskriptif hasil pengamatan peneliti terkait aktivitas fans politik pada fanspage \#2019gantipresiden.

\section{HASIL DAN PEMBAHASAN}

\section{Demokrasi Post-Penyiaran}

Kajian tentang post-penyiaran erat kaitannya dengan kajian media, lebih jauhnya mengkaji tentang wacana kebijakan. Post-penyiaran menggambarkan 
suatu cara di mana proliferasi teknologi media, saluran media dan konteks tayangan media, secara bersamaan dengan pergeseran waktu dan perangkat media seluler telah menyebabkan tingkat ketidakpastian yang tinggi di kalangan audiens media (Wilson, 2011, p. 446). Dengan begitu, audiens tidak lagi memiliki keterbatasan dalam mengakses informasi yang berkonten politis, seperti yang terjadi ketika menggunakan media penyiaran konvensional. Pun siaran yang ada di radio dan televisi diatur oleh penyiaran, sehingga audiens tidak memiliki pilihan dalam mengkonsumsi informasi dnegan konten politis.

Markus Prior (2006) menjelaskan konsep post-penyiaran adalah sebuah fragmentasi dari media yang dikonsumsi bersama, dimana media tersebut memiliki level keterikatan yang berbeda dengan muatan politik (Wilson, 2011, p. 446). Dengan begitu, post-penyiaran erat kaitannya dengan bentuk lain dari penyiaran yang dengan segala kelebihannya dapat memberikan keterikatan dengan level yang berbeda jika dibandingkan dengan bentuk penyiaran pada umumnya, yang dalam hal ini adalah radio dan televisi. Maka, media baru merupakan contoh dari bentuk post-penyiaran tersebut. Media baru juga menjadi penghubung antar sesama simpatisan untuk memperkuat ikatan di antara mereka, ataupun untuk memperkuat dukungan pada satu aktor politik tertentu. Sehingga pembicaraan tentang politik tidaklah menjadi tabu untuk diperbincangkan di media sosial.

Bennett dan Enman menyebutkan hal ini sebagai pengejawantahan dari pengalaman sosial dan politis seseorang secara lebih luas untuk dibagi bersama (Wilson, 2011, p. 446). Hal ini berarti bahwa dengan adanya kegiatan politis yang sangat luas yang dilakukan oleh simpatisan aktor politik tertentu membuat media ini dapat mempengaruhi proses pemilihan, strategi dari aktor politik, dinamika politik dalam dunia baru, serta memberikan keterikatan antar sesama simaptisan ataupun dengan aktor politik.

Couldry et.al (2010) (Wilson, 2011, p. 447) mengidentifikai bahwa hubungan antara aktor politik dengan organisasi media sekarang sudah 'melebihi anggapan dari perhatian'. Maksudnya adalah tidak ada satupun yang bisa memprediksi bagaimana kecenderungan dan perhatian dari masyarakat terhadap aktor politik tertentu dikarenakan masyarakat sudah sangat beragam dan tersebar luas untuk terpapar dengan berbagai konten politis dan mempunyai anggapan atau kecenderungan sendiri dalam menentukan arah politisnya.

Prior (2016) juga mencatat bahwa lingkungan media yang bermuatan politik pada zaman ini sudah berbeda dubandingkan tahun 1970an dan 1980an, dimana pada masa itu sifatnya adalah 'by product learning', sehingga organisasi media menjadi penentu dalam mempengaruhi arah kebijakan politis masyarakat (Wilson, 2011, p. 447). Ia juga menambahkan bawah sekarang informasi politis sangatlah beragam sehingga menumbuhkan lingkungan politis yang tidak sama rata (dalam artian tidak bisa dihomogenisasikan) serta dengan hasil kecenderungan yang tidak bisa diprediksi.

Vowe dan Henn menyebutkan bahwa televisi, radio, media cetak, sama halnya juga dengan forum debat, memainkan peranan penting dalam komunikasi politik, namun media tersebut tidak lagi menjadi tolak ukur dan dasar atas pergerakan komunikasi politik. Melainkan konstelasi aktor politik serta ritme media online menjadi penentu wacana politik dengan di tingkat tertentu dapat mempengaruhi berbagai negara, grup, dan subjek (Vowe \& Henn, 2016, p. 3).

Hal ini menjadi perhatian khusus aktivitas politik dewasa ini di berbagai belahan dunia. Media online disinyalir dapat secara efektif memberikan efek mobilitas yang tinggi erta menarik pemilih 
dengan lebih banyak. Fakta bahwa media online menjadi pilihan media kampanye bagi beberapa aktor dan partai politik dapat dipahami sebagai penanda bahwa ruang untuk mengekspresikan pendapat atas wacana politik sudah berubah. Kampanye digital menjadi alternatif strategi baru dalam menyebarkan kegiatan politik. Karena di satu sisi, kedekatan secara langsung dengna pemilih akan membentuk ikatan yang kuat dengan aktor politiknya. Di sisi lain, kedekatan ini juga menimbulkan ikatan yang bagus dalam memobilisasi internal mereka dan menarik pemilih yang belum menentukan poros politiknya bahkan bisa (Jenkins, 2006, p. 209).

Perkembangan media sosial membuat seseorang mempunyai preferensi politik sendiri. Edgerly dan Thorson (2015) mencatat beberapa penelitian tentang preferensi politik seseorang yang merupakan proses dari sosialisasi politik dan erta hubungannya dengan komunikasi yang terjadi antara dirinya dengan lingkungannya (Jennings, Stoker, \& Bowers, 2009; Linimon \& Joslyn, 2002; McLcod \& Shah, 2009) (Edgerly \& Thorson, 2016, p. 377).

Untuk itu, demokrasi post-penyiaran ditandai dengan pola konsumsi masyarakat dalam konten politik yang sudah tidak lagi bisa diprediksi, dihomogenisasikan, sangat beragam, dan tersebar luas. Sehingga cara berdemokrasi masyarakat sudah berubah tidak hanya terpapar dari media konvensional seperti radio dan televisi, namun juga secara aktif memproduksi konten politik untuk dikonsumsi secara bersama dan dalam jangkauan yang luas.

\section{Fans Politik}

Henry Jenkins dianggap sebagai founding father dalam kajian tentang fans. Walaupun penekanan Jenkins dengan studinya adalah fans di dunia hiburan, namun Jenkins juga secara inheren menyebutkan fans dalam wacana politik juga sama halnya dengan fans lainnya. Kajian fans, bagi Jenkins, merupakan pengejawantahan dari apa yang disebutnya dengan budaya partisipatif. Budaya fansseperti halnya budaya tradisional-hadir dalam berbagai bidang kehidupan secara bebas, baik dalam kehidupan formal sosial, budaya, dan institusi politik: sifatnya ekstralegal, informal, dengan partisipasi publik secara sukarela dan spontan (Jenkins, 1992, p. 279). Dengan begitu, fenomena fans tidak hanya dalam dunia hiburan saja, melainkan terjadi dalam berbagai bidang kehidupan.

Istilah "fans" berasal dari kata "fanatic" atau bahasa latinnya "fanaticus" yang berarti budak/pengikut. Namun kemudian hal ini menjadikan kata fans sendiri bermakna negatif, sehingga Oxford Lation Dictionary mengartikannya dengan: seseorang yang terinspirasi dan antusias akan sesuatu.

Seiring dengan perkembangannya, fans diartikan dalam Oxford English Dictionary sebagai seseorang yang memuja suatu agama secara berlebihan. Istilah fans menjadi populer ketika pertama kali muncul dalam bidang jurnalistik olahraga di akhir abad ke-19, untuk menyebut kepada seseorang yang tergila-gila dengan aktor olahraga daripada permainan olahraga itu sendiri. Sekarang, terminologi fans banyak dipakai untuk berbagai kajian studi kontemporer: hiburan, olahraga, politik, agama, kepercayaan tertentu, posesif, dan lain-lainnya (Jenkins, 1992, p. 21).

Alih-alih memisahkan peran produser dan konsumer, di era digital penonton tidak lagi menjadi pasif, namun mereka memainkan peran sebagai partisipan yang bahkan sejajar dengan produser yang kita sendiri bahkan juga sulit membedakannya (Jenkins, 2006, p. 3). Dengan begitu, peran dari produser dan konsumer di era sekarang sudah tidak lagi bisa dipisahkan dengan tegas. Bahkan konsumer memiki kemampuan yang lebih baik dalam memproduksi suatu teks tertentu. Fans 
sudah bertransformasi dari yang tadinya sasaran budaya populer kepada produksi dan konsumsi secara bersamaan (Jenkins, 2006, p. 12).

Hal inilah yang menjadi penanda akivitas fans yang sudah berubah di era digital saat ini. Konsumer di media baru ditandai dengan: aktif, migratori, loyal, terkoneksi secara sosial, riuh, dan publik (Jenkins, 2006, p. 19). Untuk itu dapat dipahami bahwa sifat dari konsumer media baru yang bertolak belakang dengan konsumer di media konvensional.

Dalam kaitannya dengan wacana politik, Jenkins membahas bagaimana peran publik berganti di era digital dalam tulisannya Photoshop for Democracy: The New Relatonship between Popular Culture and Politics. Jenkins melihat bahwa pergeseran peran publik dalam proses politis mengantarkan pada kondisi dimana wacana politis telah menjadi dekat dengan masyarakat, mengubah kekuatan komunitas sehingga memungkinkan untuk memobilisasi dan mentransformasi pemerintahan, serta pergeseran konsep individualistis/personal terhadap masyarakat yang menerima informasi saja (informed ciizen) kepada konsep kolaboratif dimana masyarakat menjadi pengawas atas proses politis (monitorial citizen) (Jenkins, 2006, p. 208).

Berdasarkan konsep pergeseran publik Jenkins ini, kita dapat melihat bahwa publik di era digital sangat berbeda dengan publik di era konvensional. Terkait dengan wacana politis, publik tidak hanya menerima informasi melalui satu media saja namun bisa melalui bermacam sumber infromasi yang tersedia dan hal ini membuat peran publik tidak hanya sebagai penerima informasi saja namun juga memonitor wacana politik yang ada. Informasi menjadi kekuatan baru dalam wacana politik. Kekuatan politik ini bergeser dari yang tadinya dibentuk oleh institusi dan bersifat top down, sekarang secara demokratis didistribusikan dan dibagikan kepada semua orang secara luas dan bersifat botom up (Jenkins, 2006, p. 211). Artinya adalah informasi yang disebarluaskan dari bawah keatas tentunya dapat mempengaruhi kebijakan yang akan dibuat karena mempertimbangkan animo publik yang menyebarkan informasi politis tersebut di media sosial.

Jenkins juga menggarisbawahi bahwa pola aktivitas politik baru di media sosial ini syarat dengan polarisasi dan perdebatan, baik itu perdebatan dengan otoritas pemerintah ataupun dengan perdebatan politik oposisi (Jenkins, 2006, p. 236). Hal ini terlihat dengan polarisasi yang terjadi antara suatu fans politik/partai tertentu dengan fans dari oposisi. Perdebatan atas isu politik terhadap suatu aktor/partai politik yang menimbulkan pro dan kontra dalam masyarakat, sehingga kelompok pro akan dengan segenap hati membel habishabisan, pun sebaliknya kelompok kontra akan mencari celah untuk menjelekjelekkan. Sehingga yang terjadi adalah adu ragumen antara kelompok partisan dan kelompok oposisi. Polarisasi ini justru juga menjadi hal yang oportunis bagi beberapa kelompok tertentu dan memanfaatkannya untuk memobilisasi pemilih (Jenkins, 2006, p. 236).

Menurut Prior (2016) (Wilson, 2011, p. 448), pada dasarnya semua orang yang mempunyai perhatian lebih terhadap konten-konten yang bermuatan politis dan merupakan niche audiens merupakan bagian dari fans politik. Fiorina (1990) (Wilson, 2011, p. 448) juga mengatakan bahwa fans politik tak ubahnya sepeti fans olahraga pada umunya. Fans tersebut tetap mendukung klub tertentu walau bagaimanapun hasil pertadingan setiap laganya. Pun sama halnya dengan fans politik, mereka tetap mendukung aktor politik yang mereka sukai bagaimanapun hasil pemilihan suatu kampanye ataupun citra yang dibangun aktor tersebut di mata publik. 
Dalam penelitian yang dilakukan Coleman (2003) (Wilson, 2011, p. 449) dengan membandingkan antara prilaku fans Big Brother (BB) dan Political Junkies (PJ). Ia mengidentifikasi bahwa prilaku PJ tidak hanya sebatas konsumsi mereka akan konten-konten politik, namun juga intensitas diskusi yang mereka lakukan dalam kehidupan sehari-hari dalam hubungan mereka dengan orang lain, yang kemudian mengaburkan batas antara percakapan pribadi dengan diskusi politik. Bahkan, cenderung tidak seformal media konvensional yang memang menyediakan ruang khusus untuk berbagi masalah politik.

Perkembangan ruang sosial dengan hadirnya media sosial dan media berbasis web membuat percakapan dan penyebaran konten dan informasi politik di antara fans politik semakin luas. Mengutip konsep fans Jenkins, bahwa dalam perkembangannya, fans tidak hanya menjadi audiens yang sekadar mengkonsumsi teks populer saja, namun juga secara aktif mengkontruksi dan menyebarkan makna teks tersebut (Wilson, 2011, p. 449).

Fans politik kontemporer dengan begitu menggunakan segala macam teks yang diproduksi jurnalis dan politisi untuk kemudian dijadikan bahan dan dasar dalam membentuk kreativitas dan inovasi mereka, termasuk di dalamnya menyebarkan dasar tersebut menjadi sesuatu hal yang bisa mengikat antar sesama fans politik tertentu.

\section{Pembahasan}

Sesi ini akan menjelaskan hasil pengamatan peneliti secara kualitatif dengan menggunakan metode netnografi. Hasil ditampilkan dengan membaginya kedalam beberapa penemuan. Berdasarkan observasi peneliti, penulis mengidentifikasi bahwa kemunculan fans politik menumbuhkan pola demokrasi baru, yaitu demokrasi post-penyiaran (post broadcast democracy), yang terlihat dalam: aktivitas fans politik; publik yang interaktif; produksi teks; dan pengaruh pada opini publik.

\section{Mobilitas Fans}

Aktivitas fans politik ditandai dengan mobilitas yang tinggi. Jenkins mengatakan bahwa mobilitas fans yang tinggi merupakan efek dari budaya fans. Mode partisipasi fans politik dalam menyebarkan wacana politik tak ubahnya menjadi menjelaskan bagaimana masyarakat kontemporer bisa tersebar secara luas. Ide terbesar dalam studi tentang fans adalah perubahan sosial (Brough \& Shrestova, 2012, p. 18) dan hal ini dapat memberikan dasar untuk menjelaskan bagaimana hubungan antara efek, kode budaya, dan pembentukan identitas sosial pada fans dalam proses mobilisasi.

Mobilitas yang tinggi menjadi penanda dalam melihat aktivitas fans di media sosial. Berbeda dengan media konvensional, fans peliknya tidak bisa berkomunikasi dan menyalurkan kreativitasnya secara luas. Di media sosial hal ini dilakukan jusru untuk penguatan identias sosial antar sesama fans dn itu membutuhkan pergeraka yang cepat, luas, dan tanpa batas. Berdasarkan literatur yang ditemukan penulis, terlihat bahwa dalam penelitian sebelumnya, sangatlah erat kaitan antara aktivitas yang dilakukan fans politik sebagai ciri dari budaya fans seperti yang telah dijelaskan Jenkins. Dan budaya fans ini mempunyai efek dalam menumbuhkan mobilitas yang tinggi antar sesama fans.

Giansante (2015) dalam bukunya Online Political Communication: How to Use the Web to Build Consensus and Boost Participation mengatakan bahwa penyebaran wacana politik dnegan menggunakan metode tradisional sudah tidak lagi efektif. Ini bukan berarti bahwa metode tradisional sudah tidak lagi bisa diadopsi, namun motode penyebaran baru memungkinkan perkembangan komunikasi dua-arah menjadi lebih luas, sangatlah esensial untuk membuat publik menjadi 
ingin membaca berita dan menyebarkannya kepada teman-temannya secara luas (membuatnya menjadi viral), dibandingkan harus menggunakan metode tradisional yang berarti menjual produk politik (Giansate, 2015, p. 17).

Dalam fanspage \#2019gantipresiden mobilitas fans terlihat dari postingan yang selalu diperbaharui hampir tiap harinya. Postingannya juga beragam, mulai dari pembaruan kegiatan aktor politik yang mereka dukung, sampai pada memes yang juga melibatkan oposisi. Terlebih juga postingannya mereka selalu dibagikan kembali dengan angka shares yang hampir menyamai angka likesnya. Hal ini menunjukkan bahwa mobilitas yang tinggi terjadi diantara fans-fans ini.

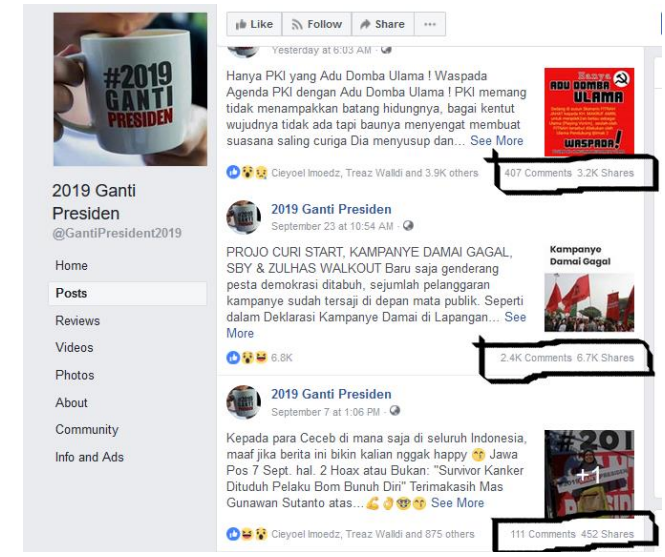

Gambar 2 Mobilisasi Fans dan Interaksi Fans Sumber: olahan peneliti

\section{Publik yang Interaktif}

Dengan penyebaran yang lebih luas, fans politik menjadi mudah untuk dapat berinteraksi baik sesama fans ataupun bukan dengan sesama fans. Terlebih dengan tidak adanya batasan bagi fans ini untuk dapat berinteraksi dengan politisi yang mereka kagumi secara langsung ataupun melalui interaksi dengan wawancara langsung politisi di salah satu media konvensional yang biasanya juga memanfaatkan media sosial untuk melihat feedback dari masyarakat. Fans pada dasarnya terlibat dalam mode resepsi dimana proses resepsi ini menyebabkan terjadinya interaksi sosial antar sesama fans (Jenkins, 1992, p. 284).

Ketika mengkonsumsi suatu teks politis, fans akan terpapar dengan atensi dan kedekatan emosional yang tinggi, sehingga mereka akan punya narasi sendiri yang kemudian ingin mereka ekspresikan sehingga fans tersebut akan memungkinkan terjadinya interaki antar sesama mereka.

Interaksi pada fanspage \#2019gantipresiden terihat dari banyaknya komentar dan interdependesi yang terjadi antar sesama fans. Begitu suatu isu muncul dan dipublikasikan, akan terdapat banyak komentar dan feedback dari fans tersebut. Mereka saling bertukar pikiran, saling berbagi informasi, dan saling menyetujui akan suatu topik yang berhubungan dengan wacana \#2019gantipresiden tersebut.

Feedback yang diberikan fans serta bagaimana fans akhirnya bisa berdiskusi baik sesama mereka ataupun mengekspresikan sesuatu hal membuat fans ini menjadi publik yang interaktif. Publik politik tidak lagi hanya dimaknai sebatas publik pasif yang menerima saja, namun juga secara aktif mengungkapkan argumennya tanpa adanya batasan untuk melakukan hal tersebut. Fans dari suatu aktor politik tertentu akan dengan mudah mengungkapkan rasa kagumnya atas tokoh politik yang disukainya setelah mendengar pemberitaan dari televisi dan mengungkapkannya melalui akun media sosial miliknya. Berbeda halnya di tahun 1980an ketika seseorang yang mendengar tokoh politik yang disukainya diberitakan, dan dia hanya bisa mengaguminya di tempat dia mendengarkan berita saja, ia tidak mempunyai wadah yang bisa menyalurkan kekagumannya secara langsung kepada semua orang.

Begitupun dengan kebijakan kebijakan politik yang dikeluarkan pemerintah. Masyarakat bisa dengan langsung mengomentarinya. Sehingga ketika suatu kebijakan dikeluarkan, biasanya pemerintah akan memantau dulu 
reaksi dan animo masyarakat yang terjadi setelah sosialisasi kebijakan dikeluarkan. Reaksi masyarakat ini akan sangat jauh jelas terlihat di media sosial. Dimana mereka bisa saja langsung mengungkapkan kesukaan ataupun ketidaksukaan mereka terhadap kebijakan tersbut. Pihak pemerintah pun bisa dengan langsung memantau bagaimana reaksi masyarakat tanpa harus menunggu lembaga tertentu dalam memantau reaksi ini.

\section{Produksi Budaya Fans Politik}

Di samping itu, perkembangan fans politik membuat begitu banyak penyebaran wacana politik menjadi lebih kreatif dan dengan banyak cara. Ada yang berupa memes, lagu, video, ataupun tulisan humoris yang dapat menarik perhatian orang banyak. Hal ini merupakan produksi teks yang dihasilkan fans. Dimana fans secara bersamaan bisa mengkonsumsi suatu teks dan bisa menghasilkan teks baik teks baru ataupun teks lama yang direproduksi kembali.

Produksi dan reproduksi teks ini terjadi dengan saling berbagi sesama fans. Banyak fans yang dengan berbagai cara kreatifnya memproduksi teks politis dan kemudian dibagikan kepada orang lain dan menjadi viral. Hal inilah yang menurut Jenkins, kegiatan produksi teks yang dilakukan fans dengan berbagai cara kreatifnya tersebut sama saja secara tidak langsung dengan menyebarkan atribut politik konvensional seperti brosur dan lainlain.

Giansante menggarisbawahi bahwa media online memungkinkan untuk menyebarkan petisi, mempublikasikan konten informasi tertentu, and membuat oarng-orang secara kolektif tergerak untuk menyuarakan suatu hal (Giansante, 2015: 63). Hal ini yang kemudian menjadikan fans politik bisa dengan mudahnya mereproduksi suatu teks, dibagikan secara bersama, dan kemudian membuat suatu wacana politik menjadi viral. Fanspage \#2019gantipresiden juga banyak menghasilkan teks-teks politis sendiri untuk mengungkapkan dukungan mereka akan aktor politik yang mreka dukung.
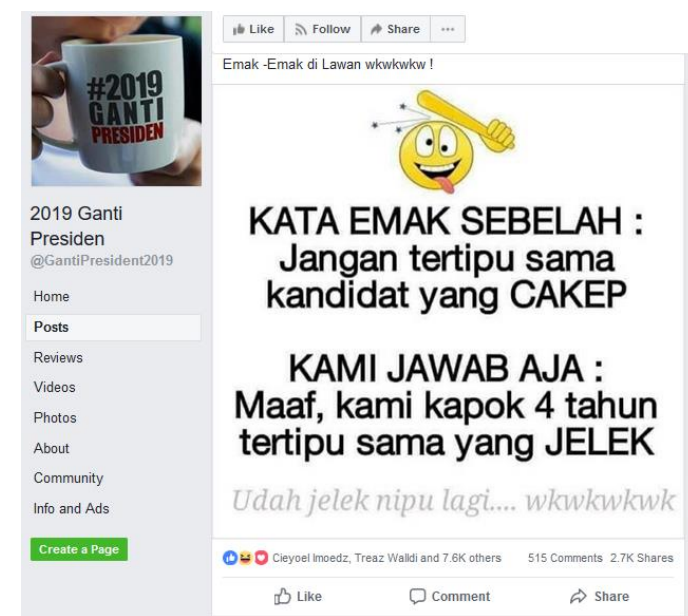

Gambar 3. Produksi Teks Budaya yang Dilakukan Fans

Sumber: Olahan Peneliti

\section{Membentuk Opini Publik}

Terakhir, kegiatan yang dilakukan oleh fans politik dapat mempengaruhi opini publik. Markus Prior (2015) mengatakan bahwa generalisasi dari sikap politik baru melalui media online ini menitikberatkan pada peran aktor politik dan informasi yang disebarkan dapat mempengaruhi dan bermakna bagi keputusan pemilihan pada saat kampanye, terlepas dari bagaimana pengetahuan politik dan kecenderungan pada suatu partai seseorang (Prior, 2015, p. 4).

Kegiatan fans ini tentunya menimbulkan polarisasi dalam wacana politik. Baik polarisasi yang terjadi di internal fans tersebut ataupun dengan sesama fans lain. Sehingga, polarisasi ini cenderung berujung pada saling adu komentar mengenai tokoh/partai politik tertentu, yang sering disebut dengan fanwar. Berbagai macam komentar, mulai dari yang bisa diterima sampai kepada komentar yang sudah tidak enak didengar bisa muncul karena polarisasi ini. Akibatnya adalah akan memunculkan opini publik terhadap suatu tokoh politik, baik itu 
opini yang mendukung tokoh/partai tersebut maupun yang tidak.

\section{SIMPULAN}

Pola demokrasi dalam perkembangan teknologi dan komunikasi di era digital telah bergeser, dari yang tadinya menggunakan media penyiaran sebagai penyalur aspirasi kepada penggunaan media baru yang dikenal dengan demokrasi postpenyiaran. Kegiatan ini merupakan produksi budaya dalam politik yang dimediasi. Menariknya, pergeseran ini justru menumbuhkan fans politik. Hal ini terlihat dari aktivitas yang mereka lakukan di media sosial.

fans Hasil penelitian terhadap aktivitas
\#2019GantiPresiden menunjukkan bahwa; pertama, aktivitas yang dilakukan fans politik di media sosial menumbuhkan konstelasi politik dengan mobilitas yang tinggi. Terlebih dengan adanya komunikasi mobile, fans dapat berinteraksi dimana saja dan kapan saja. Kedua, publik demokrasi post-penyiaran menjadi publik yang interaktif. Sifat media sosial yang memudahkan pengguna untuk berinteraksi langsung dengan pengguna lain tanpa adanya batasan membuat publik dapat menyalurkan aspirasinya dengan bebas. Ketiga, fans politik memproduksi teks yang pada akhirnya menjadi produksi budaya dalam politik yang dimediasi. Teks ini dikonsumsi dan dibagikan kepada fans lainnya sehingga membuka ruang diskusi. Keempat, aktivitas fans politik ini secara tidak langsung mempengaruhi opini publik terkait aktor politik yang mereka kagumi. Pun demikian menumbuhkan fanwar dengan fans politik oposisi. Penulis mengamati, fenomena fans politik dapat menjadi strategi baru bagi para aktor politik dalam menumbuhkan simpatisan yang fanatik dengan memanfaatkan perkembangan teknologi dan komunikasi.

\section{DAFTAR PUSTAKA}

Afriadi., Prisanto, G., Ernungtyas, N., Irwansyah, \& Afriani, L. (2019). Komunikasi Politik "Rasa" ala Jokowi dalam Merespon Politik Sentimen. Wacana: Jurnal Ilmiah Ilmu Komunikasi, 18(2), 142-153. https://doi.org/10.32509/wacana.v18 i2.928

Astuti, V., \& Toni, A. (2020. ). Media Sosial Komunitas untuk Meningkatkan Eksistensi Komunitas dalam Wacana Politik Pemilu_residen 2019. CARAKA: Journal of Communication, 1(1), 10-17.

https://doi.org/10.25008/caraka.v1i1 .38 .

Brough, M., \& Shrestova, S. (2012). Fandom Meets Activism: Rethinking Civil and Political Participation. Transformative Works and Cultures, 10, 1-27.

Burgess, J., \& Bruns, A. (2012). (Not) Twitter Election: The Dynamics of the \#autovotes Conversation in Relation to the Australian Media Ecology. Transformative Works and Cultures, 6(3), 384-402. https://doi.org/10.1080/17512786.20 12.663610 .

Creswell, J. (2014). Researh Design: Pendekatan Metode Kualitatif dan Campuran. Yogyakarta: Pustaka Pelajar.

Edgerly, S., \& Thorson, K. (2016). Developing Media Preferences in a Post-Broadcast Demcracy in Australia. In E. Thorson, M. McKinney, \& D. Shah, Political Socialization in a Media Saturated World (pp. 375-391. researchgate.net).

Fadhil. (2018, February 29). Berita. Retrieved August 22, 2018, from detikcom:

https://news.detik.com/berita/d- 
3891542/luncurkan-buku-dahnilsebut-politik-indonesia-dipenuhifans-boy

Giansate, G. (2015). Online Political Communication: How to Use the Web Build Consensus and Boost Participation. Switzerland: Springer International.

Haqqi, A. (2020). Propaganda Firehouse of Falsehood pada Pemilu 2019 di Indonesia. Wacana, 19(2), 175-185.

Hoffman, L. (2011). Going Local: Presidential Leadership in The PostBroadcast Age. Broadcasting and Electronic Media, 55(4), 611-612. https://www.doi.org/10.1080/08838 151.2011.619386.

Jenkins, H. (1992). Textual Poachers: Television Fans and Participatory Culture. New York: Routledge.

Jenkins, H. (2006). Convergence: Where Old and New Media Collides. New York: NYU Press.

katadata. (2018, February 1). katadata. Retrieved September 26, 2018, from katadata:

https://databoks.katadata.co.id/datap ublish/2018/02/01/media-sosial-apayang-paling-sering-digunakanmasyarakat-indonesia

Kozinets, R. (2010). Netnography: Doing Etnographic Research Online. London: SAGE Publications.

Lin, H. (2017). How olitical Candidates' Uses of Facebook relates to Election Outcomes. International Journal of Market Research, 59(1), 77. doi:10.2501/ijmr-2017-004.
Loader, B., \& Mercea, D. (2011). Networking Democracy? Information, Communication \& Society, 14(6), 757-769. https://doi.org/10.1080/1369118X.2 011.592648 .

Miazhevich, G. (2018). Nation Branding in the Post-broadcast era: The Case of Russian Today. European Journal of Cultural Studies, OO(0), 1-19. doi.org/10.1177/1367549417751228

Prior, M. (2015). Post-Broadcast Democracy: How Media Choice Increases Inequality in Political Involvement and Polarizes Election. New York: Cambridge University Press.

Thurman, N. (2020). When a TV Channel Reinvents Itself Online: Postbroadcast Consumption and Content Change at BBC Three. Convergence: The International Journal of Research into New Media Technologies, XX(X), 1-22. DOI: $10.1177 / 1354856520967773$.

Vowe, G., \& Henn, P. (2016). Political Communication in the Online World: Theoritical Approaches and Research Designs. New York: Routledge.

Wilson, J. (2011). Playing with Politics: Political Fans and Twitter Faking in Post-Broadcast Democracy. The International Jurnal $f$ Research into New Media Technologies, 17(4), 445-461.

DOI: $10.1177 / 1354856511414348$. 